\title{
Impact of Various Palm-Based Biodiesel Blend Mandates on Malaysian Crude Palm Oil Stock and Price: A System Dynamics Approach
}

\author{
Shri-Dewi Applanaidu ${ }^{1}$, Norhaslinda Zainal Abidin², Hasimah Sapiri ${ }^{3} \&$ M Faeid M Zabid ${ }^{2}$ \\ ${ }^{1}$ Department of Economics and Agribusiness, School of Economics, Finance and Banking, College of Business, \\ Universiti Utara Malaysia, Malaysia \\ ${ }^{2}$ Department of Decision Sciences, School of Quantitative Sciences, College of Art and Sciences, Universiti \\ Utara Malaysia, Malaysia \\ ${ }^{3}$ Department of Mathematics and Statistics, School of Quantitative Sciences, College of Art and Sciences, \\ Universiti Utara Malaysia, Malaysia
}

Correspondence: M Faeid M Zabid, Department of Decision Sciences, School of Quantitative Sciences, College of Art and Sciences, Universiti Utara Malaysia, 06010 Sintok, Kedah, Malaysia. Tel: 60-6-928-6307. E-mail: mohd_zabid@ahsgs.uum.edu.my

Received: June 14, 2015 Accepted: October 23, 2015 Online Published: October 28, 2015

doi:10.5539/ass.v11n25p190 URL: http://dx.doi.org/10.5539/ass.v11n25p190

\begin{abstract}
With an increasing concern over world population, energy security, volatile fuel prices and rising in greenhouse gas emissions, many countries are considering to a more friendly alternative fossil fuels. United States and also the European Union has already introduce of legislation mandating the use of biofuels in the energy mix. This action has stimulated the demand for vegetable oils. Malaysia is currently the largest palm oil exporter and the second largest producer after Indonesia has launched her palm-based biodiesel blending mandate of 5 percent (B5) in year 2011. However the mandate has not been implemented nationwide. Thus, this study, therefore seeks to contribute to our understanding of the impacts of various blend mandates specifically B5, blending mandate of 7 percent (B7) and blending mandate of 10 percent (B10) on the Malaysian crude palm oil market stock and price. A system dynamics model was developed for the Malaysian palm oil industry which provides a framework to understand the feedback structure and how changes in various blend mandates impact the behaviour of the crude palm oil stock and price. This research suggests that increasing the blending rate is not a favourable policy, although it managed to decrease the crude palm oil stock to the targeted level but it does not contribute to palm-based biodiesel industry production due to loss in terms of profitability because of high crude palm oil prices.
\end{abstract}

Keywords: demand, palm-based biodiesel mandate, price, supply, system dynamics

\section{Introduction}

Malaysia's palm oil industry has succeeded to be a powerful force in the global oils and fats economy over a few decades of year. Currently, Malaysia is the largest exporter and second producer of palm oil after Indonesia with an annual export value accounting to RM63.4 billion in year 2014 (MPOB, 2014). Palm oil is widely demanded by various industries like food, cosmetic, pharmaceutical, and also recently has ventured into the energy sector as a feedstock for biodiesel.

The continuous volatility and the prospect of depletion of supply in the future of world crude oil, have forced energy dependence economy in the advanced countries to seek for alternative energy, in the form of biofuel such as ethanol and biodiesel. The Kyoto Protocol is another push-factor towards biofuel demand. The protocol sets targets for industrialized countries and the European Community to reduce the greenhouse gasses (GHG) emissions. Hence the seeds for biofuel demand were planted worldwide.

Mandatory measures such as introducing legislation and subsidies were used as a start for biodiesel. A number of countries have numerical targets for domestic consumption or production of biofuels. Brazil and United States (U.S.) have backed their industries with a variety of supportive policy measures especially for the use of ethanol. 
For instance, the U.S. is targeting 20 percent of ethanol to be blended with gasoline by 2030 . The targets set by the European Union (EU) Biofuels Direction increased from two percent in 2005 to 5.75 percent by 2010 for biodiesel. By 2020, 10 percent of all conventional motor fuels in the EU will be replaced with biofuels. All these mandates were supported with massive subsidies and non-tariff protection by the U.S. and EU (Arshad, 2008).

In the case of The Association of South East Asian Nations (ASEAN) countries, mandates and investment plays an important role to boost the sector. The Indonesian government plans to replace 10 percent of its petroleum consumption with biofuel by 2020 while Thailand, supports the domestic sugar and cassava producers has mandated two percent biodiesel to be blended with diesel since February 2008 and also an ambitious 10 percent ethanol mix in gasoline starting in 2007. For a similar reason, two percent blend of biodiesel has been used in Philippines to support coconut growers.

In Malaysia, biodiesel blending mandate was launched in 2011 in the federal administration capital of Putrajaya. This was followed by Malacca on July 1, Negeri Sembilan on August 1, Kuala Lumpur on September 1 and Selangor on October 1. However the mandate has not been launched nationwide. The mandate requires diesel to contain 5 percent of biodiesel (B5). The implementation of B5 blending mandate will help to boost the production of palm-based biodiesel. With the consumption of the diesel of around 10 million per annum, approximately 500,000 tonnes of Crude Palm Oil (CPO) will be used as the feedstock for palm-based biodiesel production (Yahaya et al., 2006). This move is not only to response to the alternative fuel demand but also the opportunity for the palm oil industry to leverage on the excess stock and help to increase CPO price. In other words, biodiesel industry acts as a good buffer to support price in the case of oversupply of CPO (Hanim, 2014). The implementation of $\mathrm{B} 5$ mandate will enforce government to fix the $\mathrm{CPO}$ volume yearly even though in the reality the palm-based biodiesel producer will only produce biodiesel when the CPO price is lower than RM2000 per tonne. Furthermore, Lopez and Laan (2008) states that in the period of high CPO price, palm-based biodiesel producers may sell CPO in its crude form to leverage on its high price rather than producing POB at loss (Lopez $\&$ Laan, 2008).

This study, therefore seeks to contribute to our understanding of the impacts of various blend mandates specifically B5, B7 and B10 impact on the Malaysian crude palm oil market stock and price. Thus, a system dynamics model was developed for the Malaysian palm oil industry which provides a framework to understand the feedback structure and how changes in various blend mandates impact the behaviour of the crude palm oil stock and price.

The remainder of the paper is organized as follows: the next section briefly reviews the literature on previous studies on palm oil industry especially on the biofuels. The methodology used for examining the market variable behaviour is in Section 3. Section 4 is the results and analysis and finally some conclusions are presented in the last section.

\section{Literature Review}

There are many studies has been modelled in the Malaysian palm oil industry using econometric models. A study by Ramli et al., (2007) on the impact of palm-based biodiesel demand on palm oil price was the first attempt to include biodiesel demand in the price equation by using time varying parameter. Another study by Shri Dewi et al., in 2011 analysed the link between biodiesel demand and Malaysian palm oil market by using econometric method using annual data for the period 1976-2008 (Shri, Arshad, Shamsudin, \& Hameed, 2011a). This study included the role of stationarity and cointegration as a prerequisite test before proceeding to the simultaneous equation estimation procedure. Further, Shri Dewi et al. in 2011 have extended the study by examining the link between biodiesel demand, petroleum prices and palm oil market (Shri, Arshad, Shamsudin, \& Yusop, 2011b). The impact of biodiesel demand on the Malaysian palm oil industry by using simultaneous equations approach was done by Shri Dewi et al. in the same year (Shri, Arshad, Yusop, Shamsudin, \& Alias, 2011c). In terms of biofuel impact studies using system dynamics models mostly focused in EU and U.S. (Bantz \& Deaton., 2006; Papachristos \& Adamides 2012; Franco, Ochoa, \& Florez, 2009). However, there is also a study by Hidayatno et al. in Indonesia (Hidayatno, Sutrisno, Zagloel, \& Purwanto, 2011) and Yahaya et al. in Malaysia (Yahaya, Sabri, $\&$ Kennedy, 2006). Both of the studies in Malaysia examine the biodiesel, crude palm oil and petroleum price linkages.

In terms of biofuel mandate impact studies in Malaysia, Shri Dewi et al. in 2014 examined the impact of B10 on the Malaysian palm oil market using structural econometric models (Shri Dewi, Ali, \& Alias, 2014). The study indicates that counterfactual simulation of an increase from B5 to B10 predicts a positive increase (23.31 per cent) in palm oil domestic consumption, 109.3 per cent decrease in stock, 0.07 per cent increase in domestic price of palm oil and a marginal (0.05 percent) increase in production. FAPRI (2007) examined that the increase 
in biofuel mandate to the level specified in Energy Saving Act of 2007 through 2015 resulted in a 2.6 billion gallon average increase in U.S. ethanol use in 2015, relative to the baseline. Most of the increase is supplied by an increase in production of U.S. corn-based ethanol. The mandate also leads to an increase in the producer prices for ethanol to generate the required level of ethanol supplies. The estimated increases are small in early years, as the required changes in ethanol supplies are modest relative to the baseline. The increase in corn demand results in higher corn prices, with the increase relative to the baseline reaching USD0.20 per bushel (6.6 percent) by 2015. Meanwhile, in soybean market, the mandate increases the demand for soybean oil to make biodiesel. This in turn reduces domestic demand for soybean meal. The net effect of the reduction in soybean production and the changes in product markets increases soybean price. Higher soybean prices, in turn contribute to reduction in soybean domestic use and export. In 2015, domestic soybean reduces by 14 million bushels relative to the baseline, while export reduces by 32 million bushels.

Birur et al., in 2007 concludes that development in the U.S. EU biofuels market with the 5.75 percent biofuel mandate, were likely had significant and lasting impact on the global pattern of agricultural production and trade (Birur, Hertel, \& Tyner, 2007). Anderson and Coble (2010), investigated the potential impact of ethanol mandates on equilibrium corn prices and quantity, which focused on how the mandates influence market participant expectations. Results showed that due to the stochastic nature of supply and demand shocks, even a mandate that was technically nonbinding can have substantial impact on corn prices and quantities through the mandate's impact on the price responsiveness of demand from ethanol sector. Results suggest that on average for the simulated outcomes, the price response associated with the Renewable Fuels Standard (RFS) mandate was about 6.5 percent greater with the elasticity of -2.75 than with the elasticity of -1.75 .

Acheampong et al. studied the impact of biofuel mandates and switch grass production on hay markets (Acheampong, Dicks, \& Adam, 2010). The RFS mandates will require 36 billion gallons of ethanol to be produced in 2022, 16 billion gallons of which is to be produced from cellulosic feedstock. To meet the mandate, it is estimated that 24.7 million acres would be used to produce 109 million tonnes of switch grass in 2025. Since the majority of these acres likely would be converted from land currently producing hay, cattle production will be reduced. Thus the chronological impact of biofuel mandates on cattle market were linked by hay production and price.

To date, little research has specifically addressed various blend of biodiesel mandate impact in the Asian context especially in Malaysia with the exception by Shri Dewi et al., (2014) where only focuses on B10 mandate impact. We will incorporate these factors into our analyses. Finally, we are unaware of any studies using more recent data in a system dynamics models to examine the mandate impact on the Malaysian crude palm oil market especially on the stock and price.

\section{Methodology}

\subsection{The Concept of System Dynamics}

System dynamics rooted from the invention of industrial dynamics by J. Forrester in 1961 (Forrester, 1961). Since then, it has been developed and used to model complex systems that entail variables and its inter-relationship with each other. It promotes and facilitates the analysis process of non-linear relationship of variables in a complex system. The main advantage of system dynamics is its feedback. There are two main feedbacks that becomes the core structure of system dynamics: positive and negative feedback. Positive feedback impose a reinforce loop, where one variable effect will increase the effect of another variable. Negative feedback on the other hand imposes a balancing feedback, where one variable effect will balance out the effect of another variable (Sterman, 2000). System dynamics emphasize the importance of overall dynamics trends such as exponential, asymptotic and oscillation in explaining a system.

In system dynamics, there are two important diagrams: the causal loop diagram (CLD) and stock and flow diagram (SFD). CLD are drawn to capture the qualitative model at the beginning of the modelling process. It helps in projecting the cause and effect relationship and feedback among variables. Variables are linked by arrows with appropriate polarity based on their relationship and show the direction of influence. Positive polarity exhibits a direct influence, while negative polarity exhibit inverse influence.

SFD is drawn after completing CLD. Unlike CLD, SFD conjures the actual dynamics of the system. It consists of stock variable, flow variable, auxiliary variable and link as its main build. Stock variables (also known as accumulation or state or level) show the state of the system at one particular time. Flow variables determine the value of stock, where net flow (difference between inflow and outflow of a stock) will cause the value of stock to increase or decrease. Auxiliary variables are calculated from other variables within the system, which specifies the decision rules that carries information between system components. The connections between the variables 
were established through links. Links act as a connector in the form of arrow defining the connection and control between the variables in the system.

\subsection{Model Conceptualization and Data}

A generic structure of commodity model has been presented in Sterman (2000), adopted from Meadows (1970) which includes key variables such as supply, demand, price and profitability. This is a good reference in developing other commodity market model. The underpinning concepts of the structure is that demand depends on price and price depends on the availability of products in inventory, while the inventory is depending on the demand. The same concepts are applicable in the palm oil commodity system.

In this study, a system dynamics model has been constructed to help in understanding the impact of various blend mandates (B5, B7 and B10) towards Malaysia crude palm oil stock and price. Figure 1 shows the CLD of this study. There are two balancing loops B1 and B2. The balancing loop B1 represents the supply and demand loop. As CPO stock is accumulated from CPO production and CPO import, it will be depleted with the increase of total CPO demand. Low CPO stock will increase CPO price, which in turn will decrease the total CPO demand. Low total CPO demand will increase the CPO stock and the cycle continues.

The balancing loop B2 represents the palm-based biodiesel (POB) profitability loop. High CPO price will result to high $\mathrm{POB}$ production cost, which in turn will lower the POB profitability. Low profitability will lower the CPO demand for POB demand and total CPO demand. Lower total CPO demand will increase CPO stock and subsequently decrease back the CPO price, and the cycle continues. Note that CPO demand for POB is determined by POB mandate imposed by government. Note also that POB profitability is affected by the increase of crude oil price.

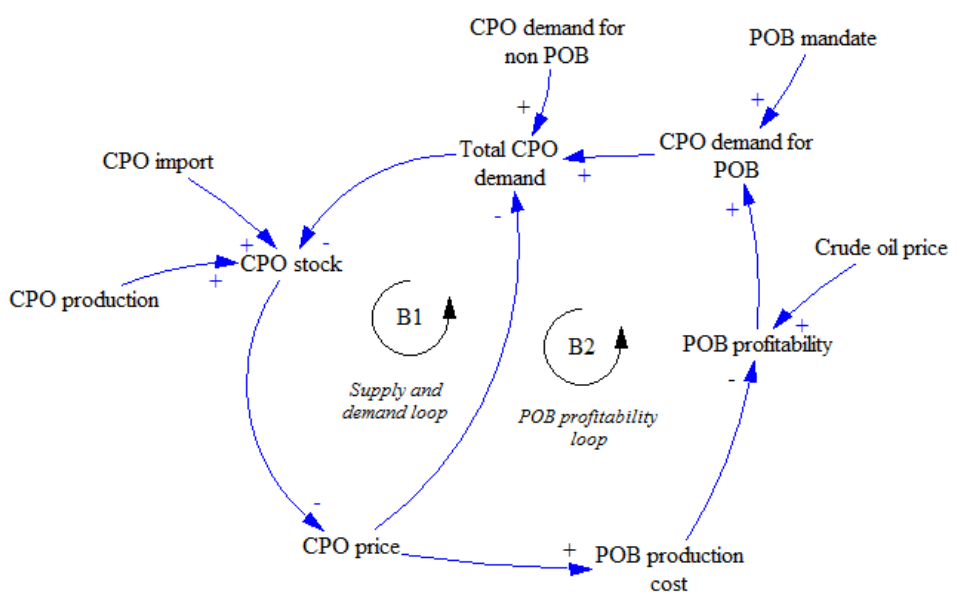

Figure 1. Causal loop diagram of the study

Secondary data from Malaysian Palm Oil Board (MPOB), Department of Statistics of Malaysia and various published sources were used for model construction and validation. The simulation covers the period of 2000-2020.

\subsection{Model Formulation}

After constructing CLD, the SFD was built to enable further analysis on model dynamics and experimenting different policy scenarios. The SFD constructed in this study is consisting of three sub-models: supply and demand, $\mathrm{POB}$ demand and $\mathrm{POB}$ profitability. 


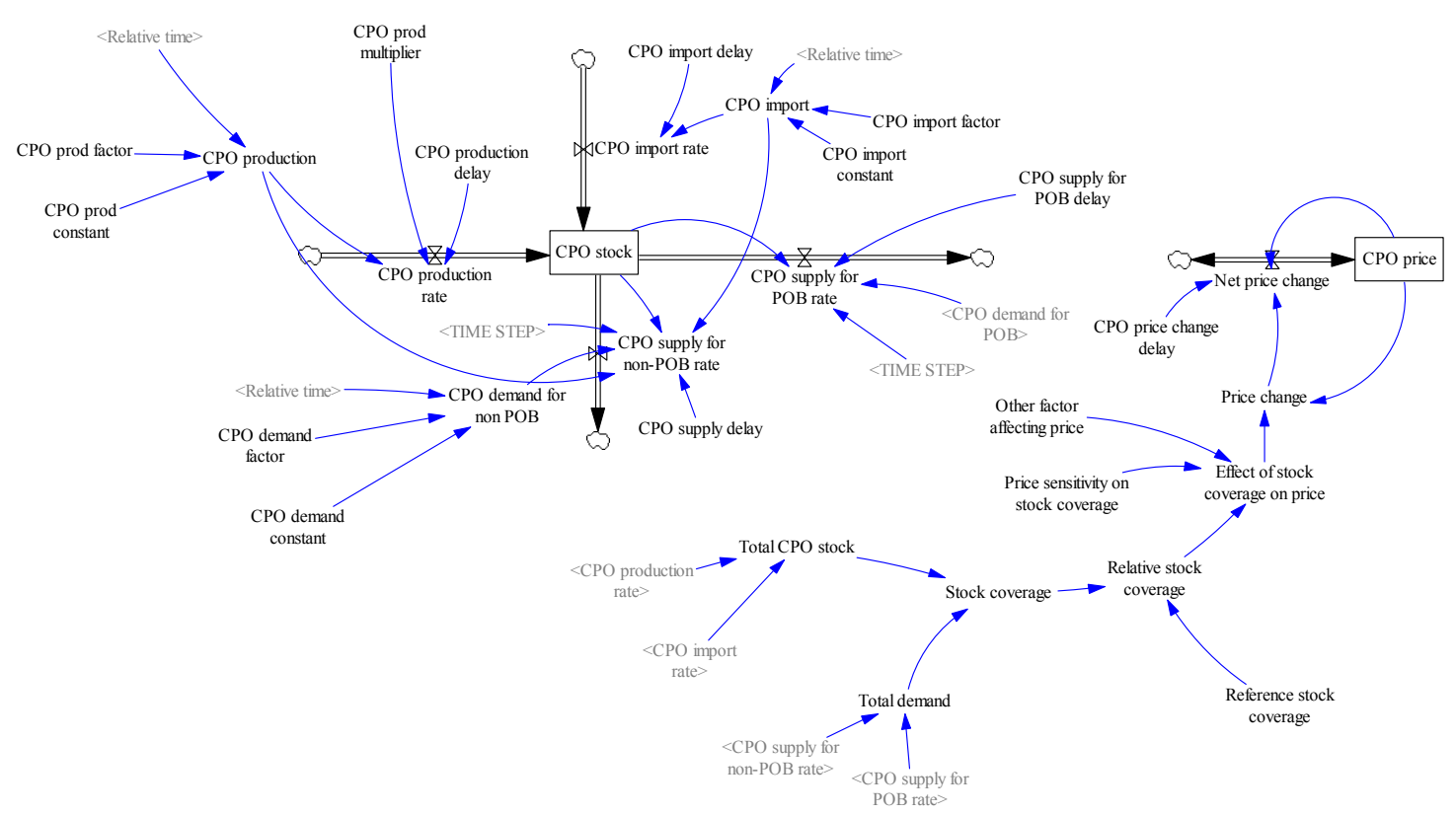

Figure 2. Supply and demand sub-model

Figure 2 shows the supply and demand sub-model. There are 29 variables and 2 stock in this sub-model. $C P O$ stock is the accumulation of $\mathrm{CPO}$, with $C P O$ production rate and $C P O$ import rate as its inflows, and $C P O$ supply for $P O B$ rate and $C P O$ supply for non $P O B$ rate as its outflows as per Equation 1.

$$
\text { CPOstock }=I N T E G\left(\begin{array}{l}
\text { CPOproductionRate }+ \text { CPOimportRate }- \\
\text { CPOsup plyForPOBrate }+ \text { CPO sup plyForNonPOBrate, CPOstock }
\end{array}\right)
$$

We also have $C P O$ price modelled in the form of stock in this sub-model. $C P O$ price is the accumulation of net price change overtime (refer Equation 2). The agent of change in price is the stock coverage. Stock coverage or inventory coverage is the ratio of existing inventory level to consumption (Sterman, 2000). When stock coverage is higher than reference stock coverage (average value according to historical data), the price will be decreased and vice versa. Note that effect of stock coverage on price is affected by price sensitivity on stock coverage and other factor affecting price. Price sensitivity on stock coverage indicates the level of sensitivity of CPO price with the change of stock coverage. Other factor affecting price is other possible factor (like price of soybean) that may affect the CPO price trend but is not being explicitly modelled in this study, but instead being represented in a constant value.

$$
\text { CPOprice }=\text { INTEG }\left(\text { Net } \text { PriceChange }, \text { CPOprice }_{0}\right)
$$




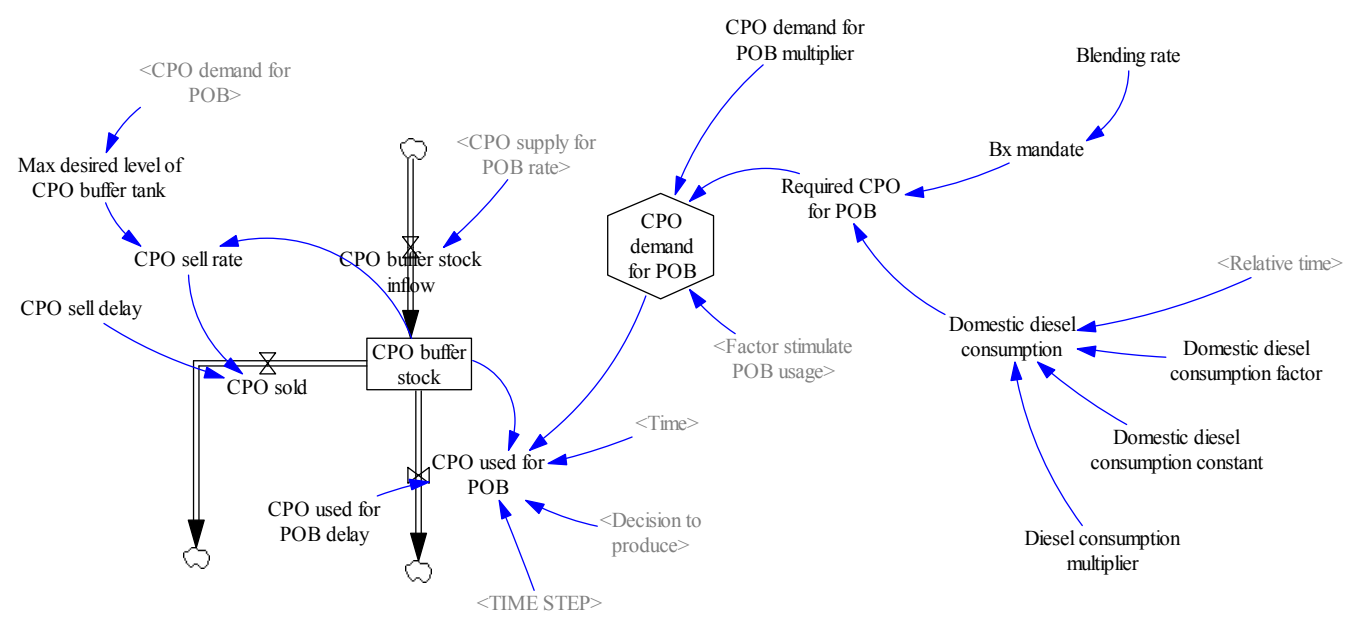

Figure 3. POB demand sub-model

Next, is the POB demand sub-model (refer Figure 3). This sub-model consists of 16 variables and 1 stock. In the POB demand sub-model, the compulsory purchase of CPO will be stored in CPO buffer stock (refer Equation 3). CPO buffer stock will be utilized either through the production of POB during the profitable period; or will be sold when the price of CPO is high (Lopez \& Laan, 2008). In the profitable period, $C P O$ used for POB will utilize the CPO buffer stock to produce POB according to the demand. Note that CPO used for POB is affected by decision to produce. Decision to produce determines the profitable period for POB producer to produce POB and will be explained further in the next sub-model. $C P O$ demand for $P O B$ is mainly determined by the $B x$ mandate imposed by the government at certain blending rate. Current implemented blending mandate is B5, which means 5 percent of palm oil will be blended with 95 percent of petrol diesel. Required CPO for POB is then calculated by multiplying the Bx mandate with domestic diesel consumption.

$$
\text { CPObufferStock = INTEG (CPObufferStockInflow-CPOusedForPOB } \left.- \text { CPOsold, CPObufferStock }{ }_{0}\right)
$$

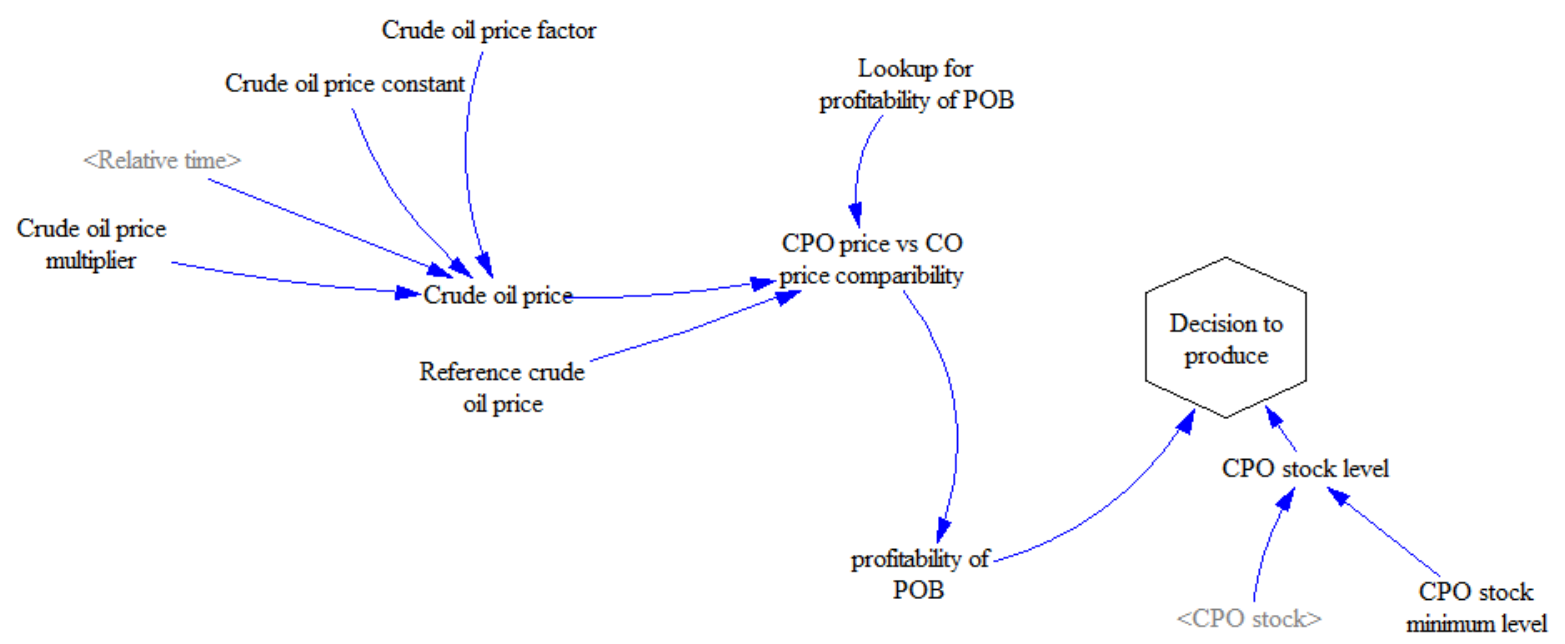

Figure 4. Profitability of POB sub-model

Figure 4 shows the profitability of POB sub-model. This sub-model elaborates further the decision to produce variable. Decision to produce indicates the suitable period for POB producer to produce POB. It is determined by two factors, which are the profitability of POB (Lopez \& Laan, 2008) and CPO stock level (Hanim, 2014) as 
per shown in Equation 4.

$$
\text { DecisionTo Produce }=f(\text { profitabilityOfPOB, CPOstockLevel })
$$

Profitability of $P O B$ is affected by the $C P O$ price vs crude oil $(C O)$ price comparability. CPO price vs CO price comparability indicates that various combination of $\mathrm{CPO}$ and $\mathrm{CO}$ price will result in variants of $\mathrm{POB}$ profitability (as per reported in past studies and compiled by Lopez and Laan (2008)). Figure 5 shows the table lookup for profitability of POB. Any CPO price at a particular crude oil price that falls below the line is deemed as profitable, while CPO price above the line is assumed as non-profitable for POB production. Generally, lower CPO price and higher CO prices combination will lead to higher POB profitability. CPO stock level on the other hand indicates the feasible POB production period when the CPO stock level is more than the CPO stock minimum level. It is reported that the aim of $\mathrm{POB}$ production is to reduce the domestic palm oil inventory to below 1 million tonne annually to control the CPO prices (Hanim, 2014). Thus it can be concluded that the CPO stock level should be below 1 million tonne and above the CPO stock minimum level (we do not want the stock to be completely zero, thus small margin like 50,000 tonne will be set as CPO stock minimum level).

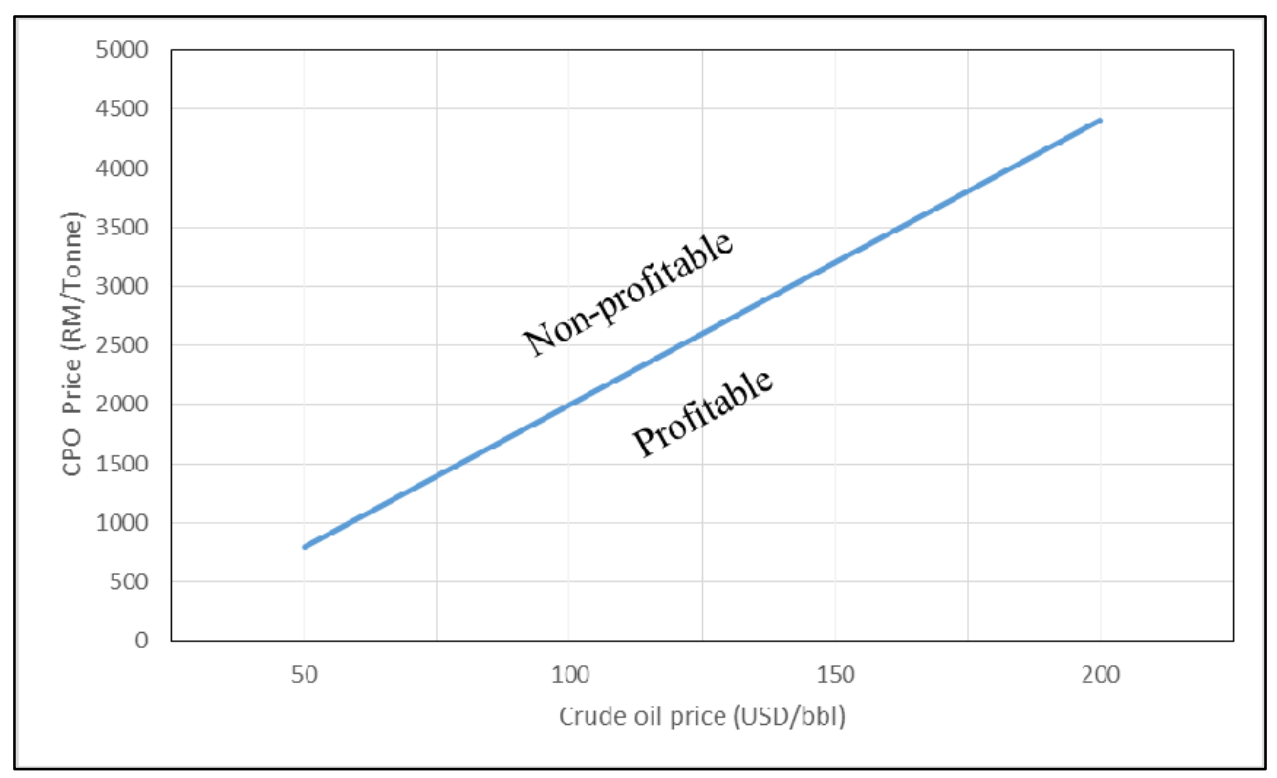

Figure 5. Table lookup for profitability of POB (Taken from Lopez \& Laan, 2008)

\section{Results and Analysis}

\subsection{Model Validation Results}

Validation test is an important pre-requisite test to ensure that the constructed model is robust enough and sufficiently reliable in representing the real system. We have conducted two most important tests on our model.

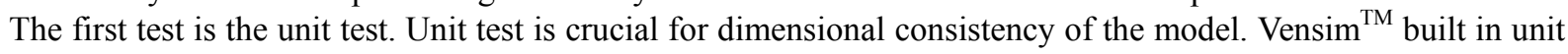
test has been used for unit test and the model shown no error in terms of dimensional consistency (refer Figure $6)$. 


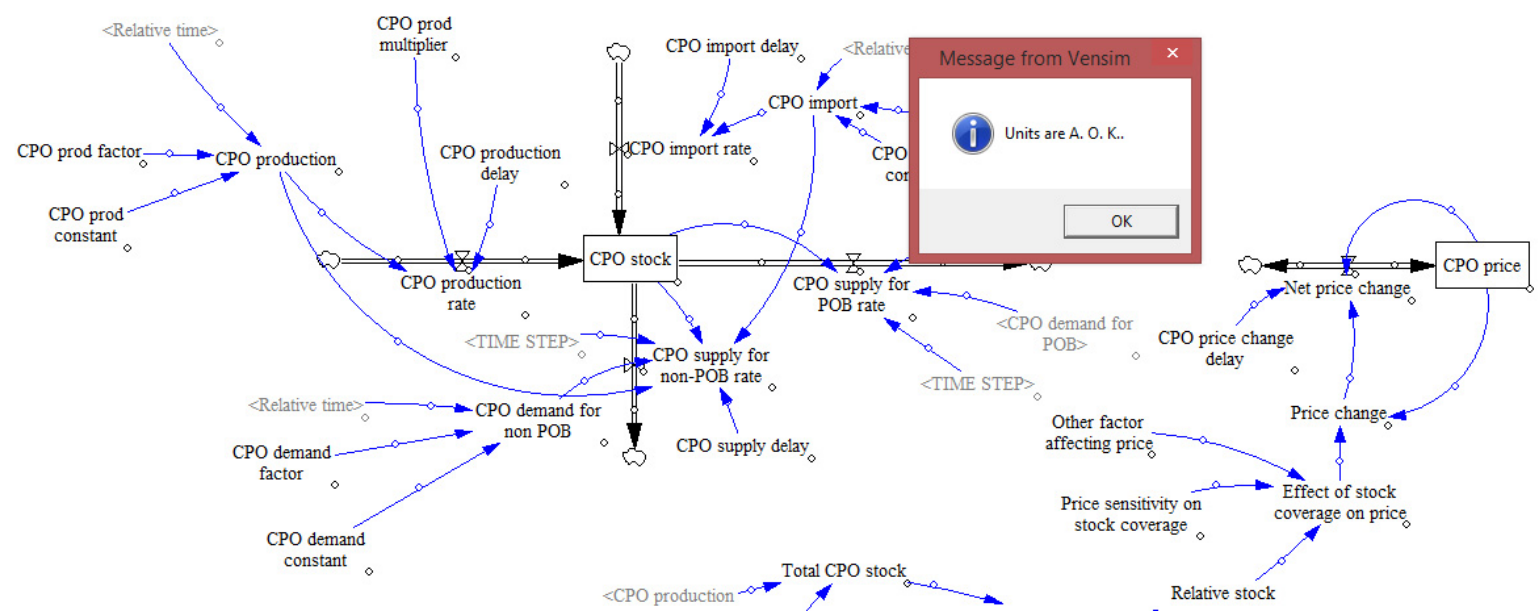

Figure 6. The model unit test

The second test is the integration behavioural test. Test is performed by changing the delta time $(d t)$ for integration time step. It is expected that a particular stock behaviour does not change significantly when time step is reduced. As the overall behaviour pattern for all stocks in the model are almost identical as per Figure 7, 8, and 9 for every tested time step, the model has passed the integration test.

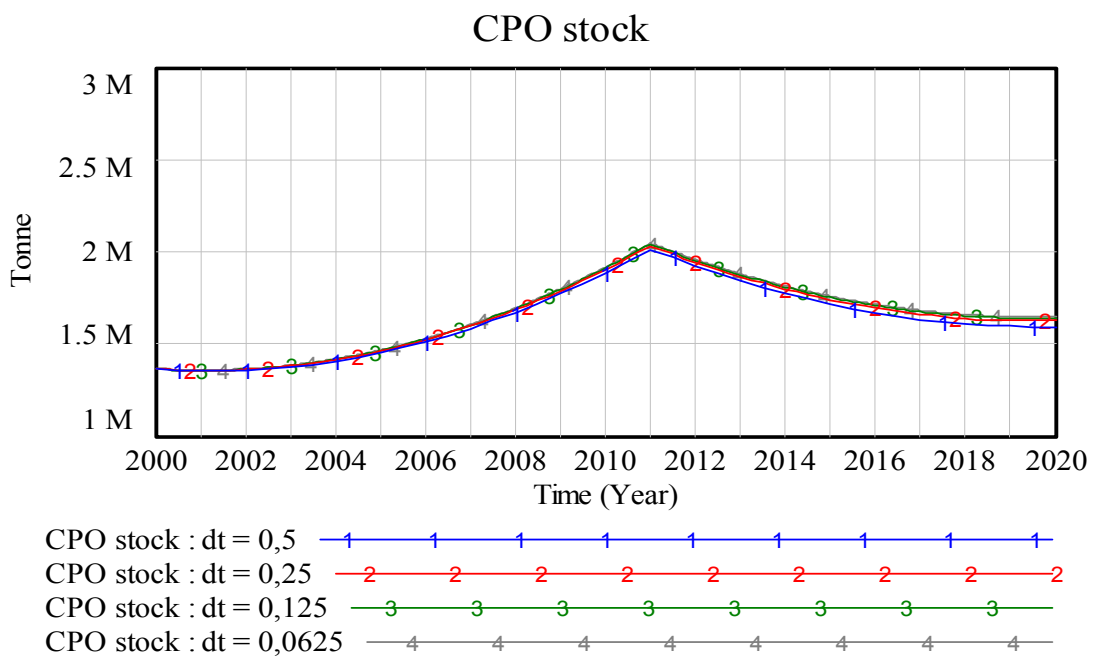

Figure 7. CPO stock for various time step value 


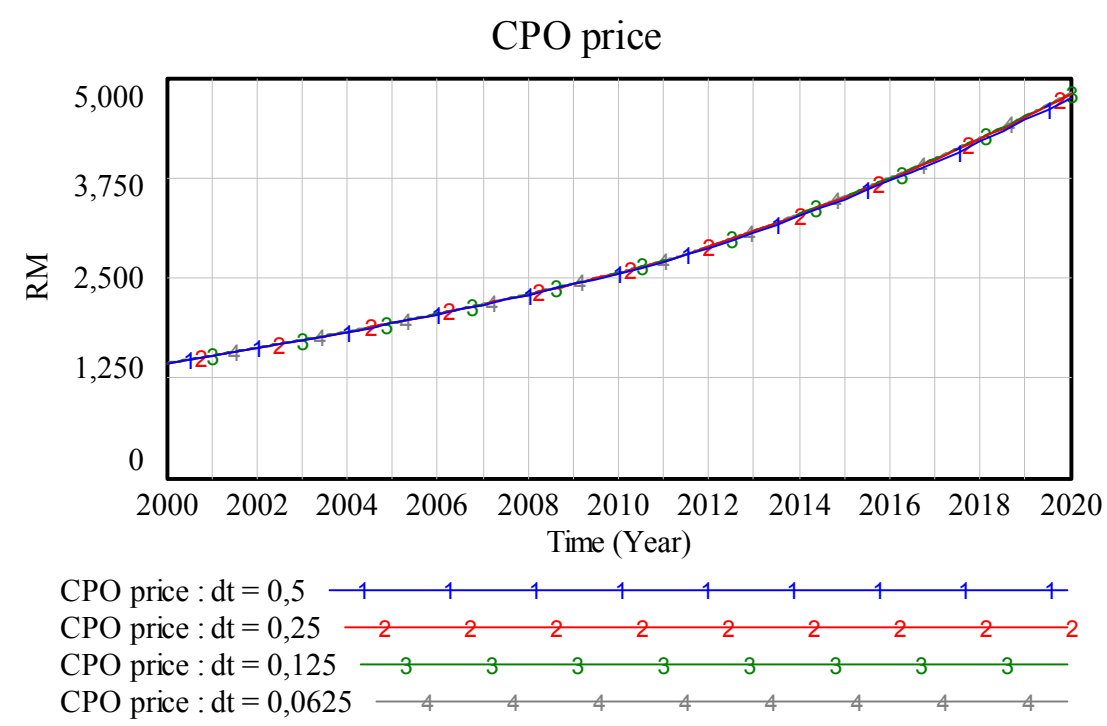

Figure 8. CPO price for various time step value

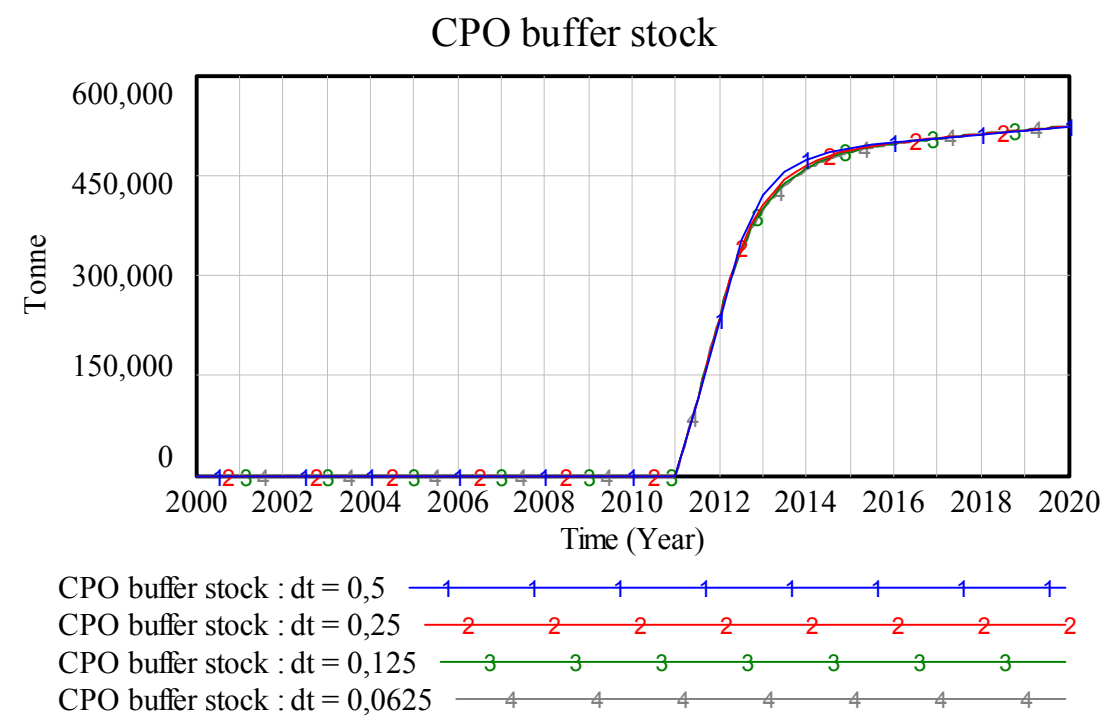

Figure 9. CPO buffer stock for various time step value

\subsection{Model Simulation and Findings}

The model is simulated in three different scenarios with various blending rates to analyse the impact it has on the Malaysian palm oil industry dynamics. First scenario (baserun) is the current implemented scenario with the 5 percent blending rate, while blending rate is increased to 7 percent and 10 percent in second and third scenario respectively. Table 1 summarizes the scenarios tested. Model has been simulated from year 2000 until year 2030, and the POB mandate will only start from year 2011.

Table 1. Value for key variables for all tested scenarios

\begin{tabular}{ll}
\hline Scenario & Blending rate \\
\hline 1 (Baserun) & $5 \%$ \\
2 & $7 \%$ \\
3 & $10 \%$ \\
\hline
\end{tabular}


Figure 10 shows the $C P O$ stock for all tested scenarios. Compared to the baserun, increasing the blending rate has resulted to the depletion of CPO stock. Blending rate of 7 percent and 10 percent has both successfully decreased the CPO stock level below 1 million tonne by year 2020 as targeted (Hanim, 2014). This is due to the increase in $C P O$ demand for $P O B$ as per Figure 11. By increasing the blending rate to 10 percent, the $C P O$ demand for $P O B$ recorded an increase of 100 percent, which is coincide to the finding by Shri Dewi et al., (2014) that stated a 109 percent increase in $C P O$ stock for $\mathrm{POB}$ production with $\mathrm{B} 10$ mandate in their simulation.

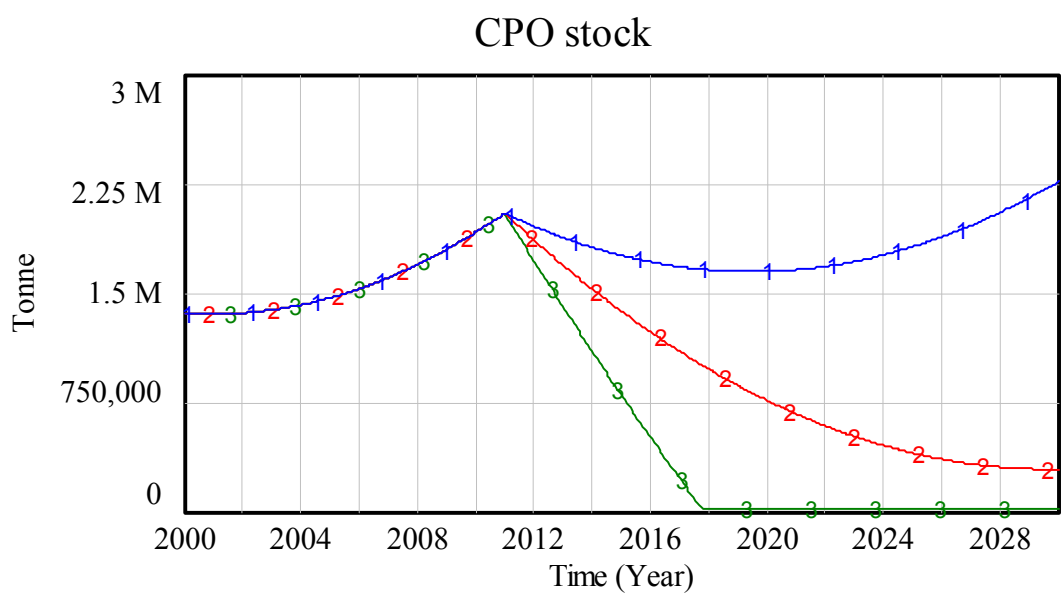

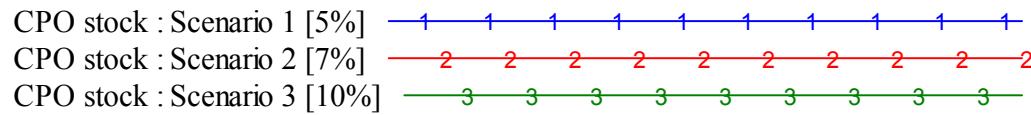

Figure 10. CPO stock for all tested scenario

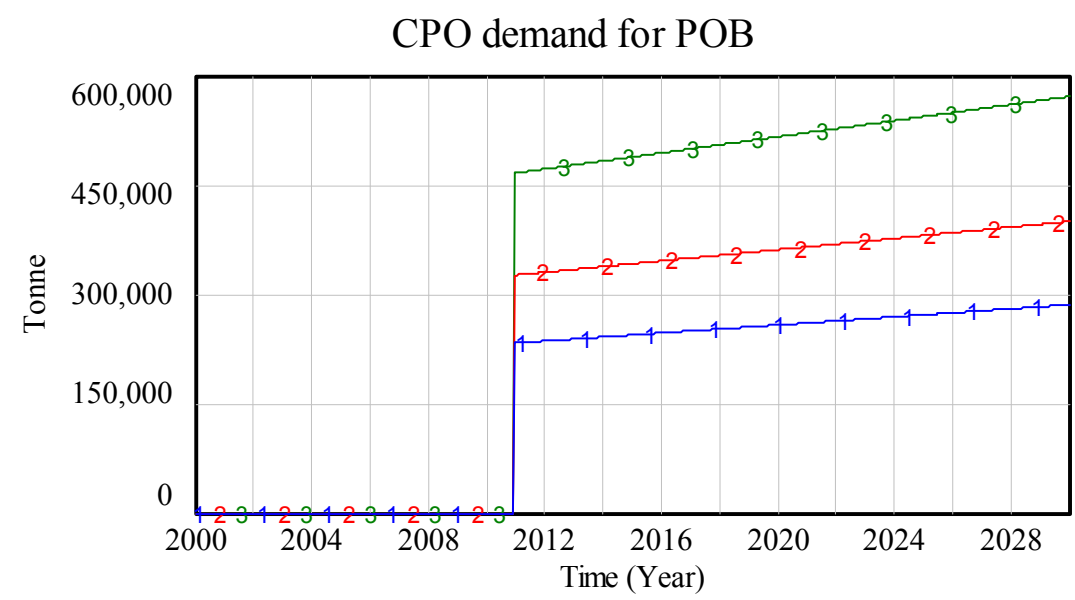

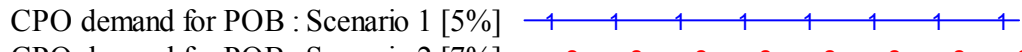

CPO demand for POB : Scenario 2 [7\%] $\begin{array}{llllllll}2 & 2 & 2 & 2 & 2 & 2 & 2\end{array}$

CPO demand for POB : Scenario $3[10 \%]$ l $\begin{array}{lllllll}3 & 3 & 3 & 3 & 3 & 3\end{array}$

Figure 11. $C P O$ demand for $P O B$ for all tested scenarios

With the decrease of $C P O$ stock, $C P O$ prices have responded in an increasing trend as per shown in Figure 12. Note that the higher the blending rate, the steeper the slope of $\mathrm{CPO}$ prices become. By increasing the blending rate to 10 percent, approximately 0.075 percent increase in $C P O$ prices is recorded. This finding also similar to the finding by Shri Dewi et al., (2014) that recorded 0.07 percent of CPO prices increment with B10 mandate. 


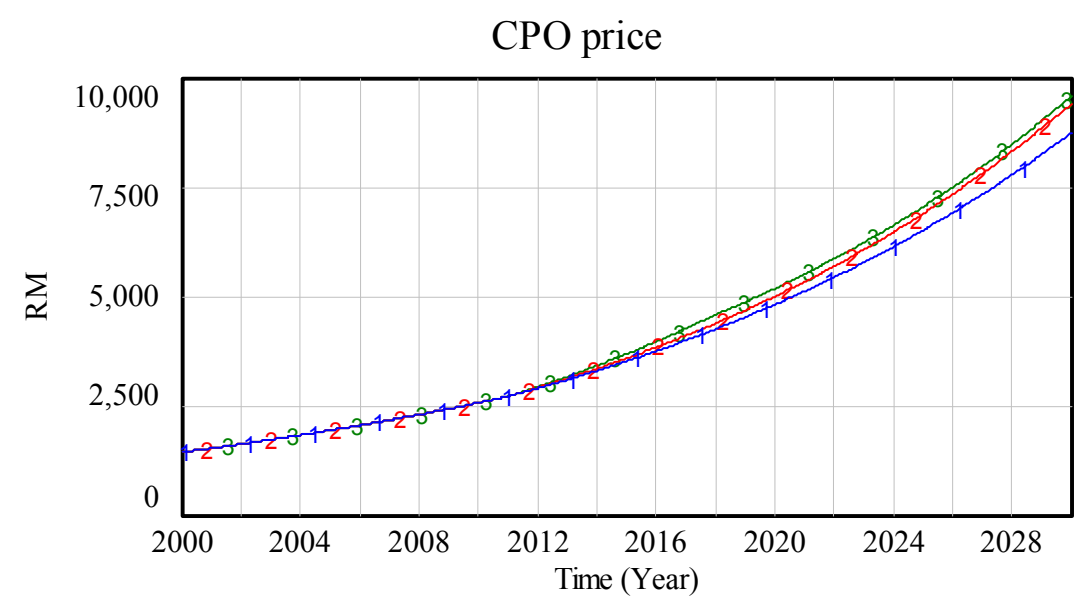

CPO price : Scenario $1[5 \%]$
CPO price : Scenario $2[7 \%]$
CPO price : Scenario $3[10 \%]$

Figure 12. CPO price for all tested scenarios

Next, we are also looking at the $C P O$ used for $P O B$ production (refer Figure 13). Even though the CPO stock has been decreased with the increasing of blending rate, but it did not contribute much to the production of POB industry. Starting from year 2011 onwards, no production activity can be seen in all scenarios. This is due to zero decision to produce (or in other words no feasible period to produce POB) because of low profitability (refer Figure 14 and 15). Higher $C P O$ prices are the main reason for zero productivity. These findings indicate that increasing the blending rate has no benefit in contributing to the production of POB industry. The locked purchase of $\mathrm{CPO}$ in $\mathrm{CPO}$ buffer stock is otherwise being sold in its crude form to exploit on its high price as per stated by Lopez and Laan (2008).

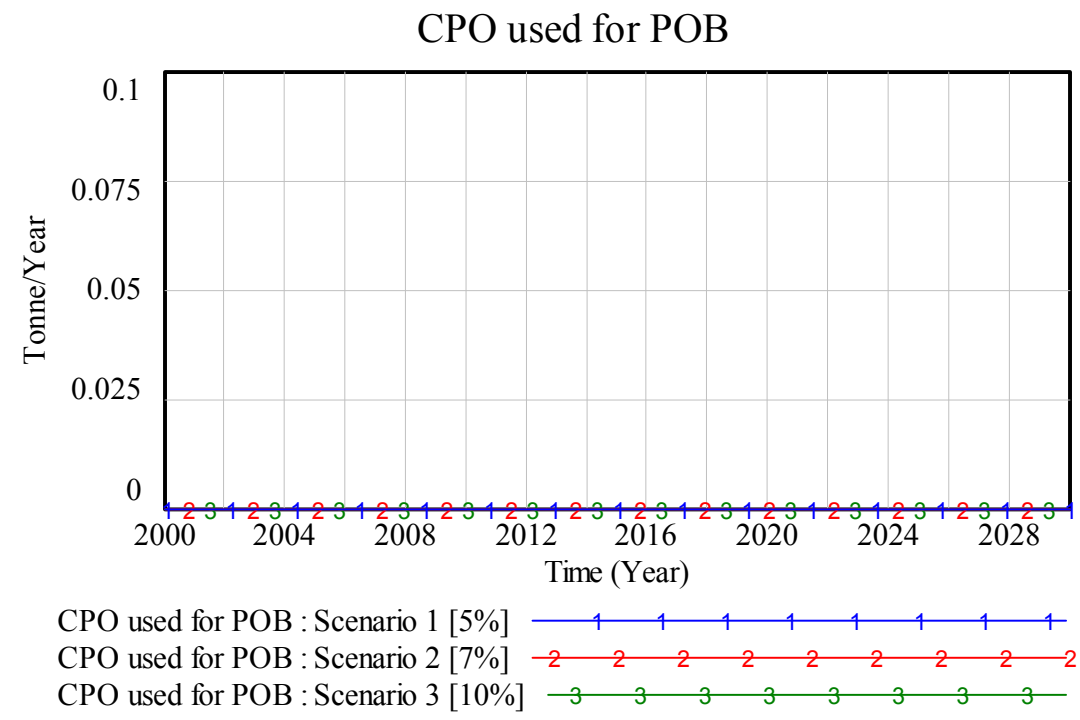

Figure 13. $C P O$ used for $P O B$ for all tested scenarios 


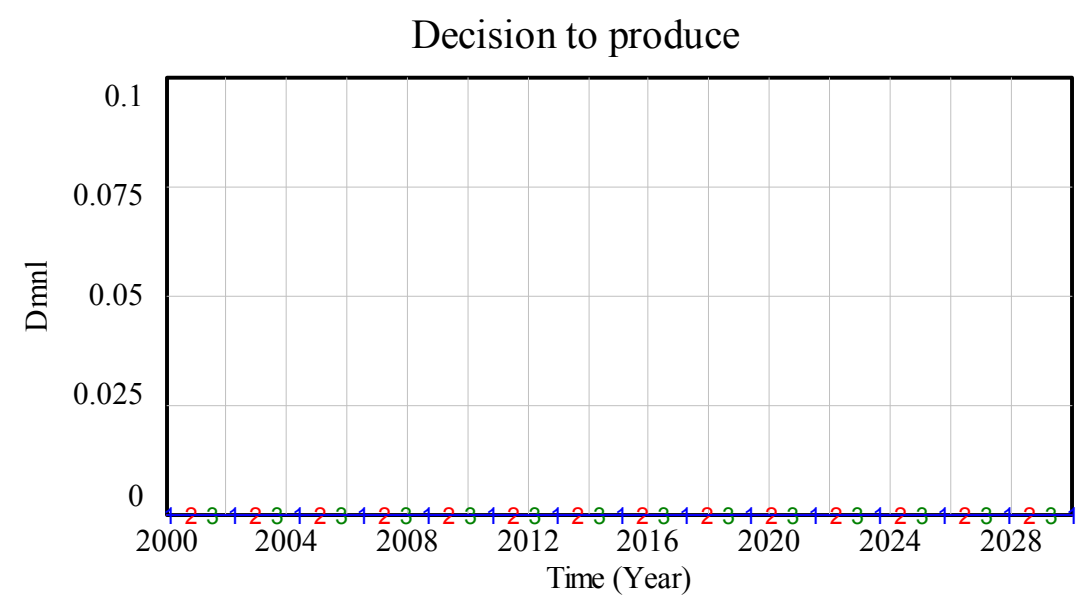

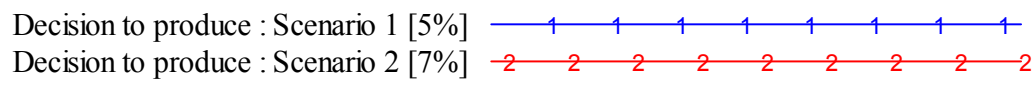

Decision to produce : Scenario $3[10 \%]$ - $\begin{array}{llllllll}3 & 3 & 3 & 3 & 3 & 3 & 3\end{array}$

Figure 14. Decision to produce for all tested scenarios

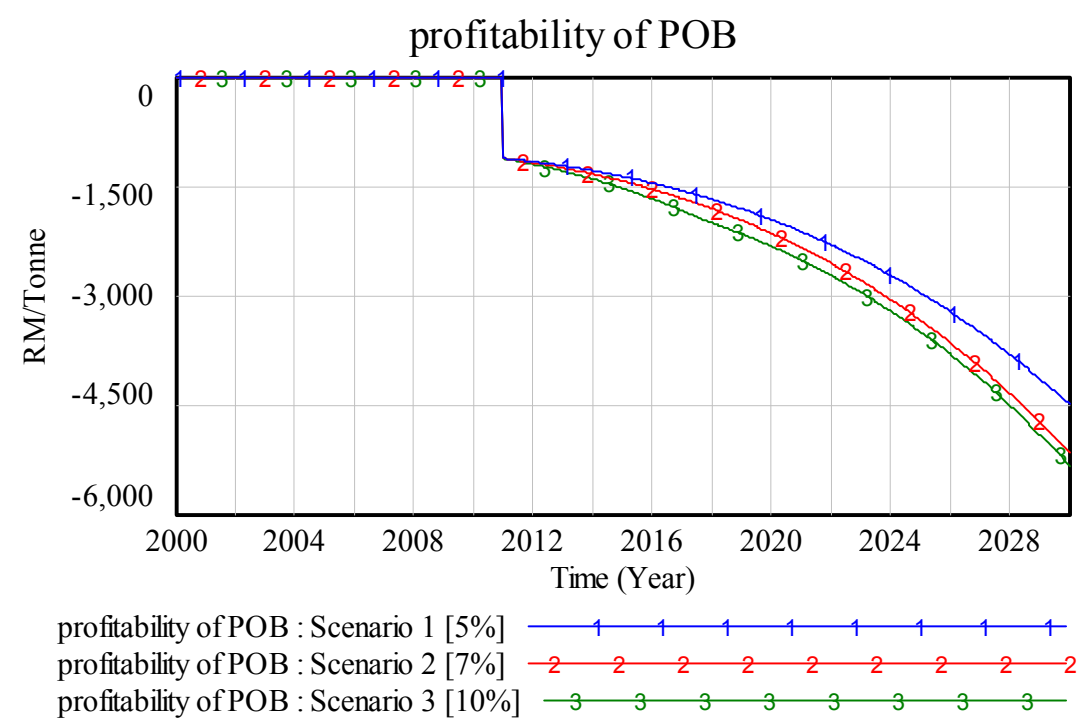

Figure 15. Profitability of $P O B$ for all tested scenarios

Figure 15 also shows one more important finding. Even in the current setting (B5), the POB producer is producing at loss amounting to approximately -RM 1900/tonne by year 2020 .

\section{Conclusions}

Biodiesel can be considered as an infant industry in Malaysia which has recently ventured by the palm oil industry in order to diversify the use of palm oil through the National Biofuel Policy. Through the system dynamics model constructed in this study, we have analysed the potential impact imposed by the implementation of various blending mandate on Malaysia palm oil industry dynamics.

The findings show that increasing the blending rate will increase the CPO demand for POB production, resulting a decrease of CPO stock and subsequently increasing the CPO price. However, increasing POB demand will only increase the amount of compulsory CPO purchase (or locked purchase) by government with no additional contribution to the production of POB industry, as the production of POB is highly dependent on the profitability of POB. From the analysis, it can be concluded that increasing the blending rate is an unfavourable policy, unless the government favour in terms of incentives or subsidies to encourage the development of palm-based industry. 
This study tend to look at POB profitability from general view to see the impact of various biodiesel blending mandates on CPO stock and price. However, it is arguable that other factors like capital cost, production cost and return of investment has to be incorporated for more accurate analysis of biodiesel industry profitability. Thus in the future, we will include the life cycle cost and sensitivity analysis using SD approach to investigate further the impact of various blending mandates on POB profitability. We also will incorporate government subsidies as a variable in our model and simulate the important role of this variable towards the Malaysia palm oil industry in our future research.

\section{Acknowledgements}

We would like to thank many individuals and organizations who assisted us during the study, which are too numerous to mention. A special thanks to Ministry of Higher Education, Universiti Utara Malaysia (UUM) and Research and Innovation Management Centre (RIMC), through Research Acculturation Grant Scheme (12716).

\section{References}

Acheampong, K., Dicks, M. R., \& Adam, B. D. (2010). The Impact of Biofuel Mandates and Switchgrass Production on Hay Markets (pp. 19-20). St. Louis, Missouri.

Anderson, J. D., \& Coble, K. H. (2010). Impact of Renewable Fuels Standard Ethanol Mandates on the Corn Market. Agribusiness, 26(1), 49-63. http://dx.doi.org/10.1002/agr.20202

Arshad, F. M. (2008). Palm Oil Based Diesel: An Inconvenient Opportune? Impak. Quaterly DOE Update on Environment, Development \& Sustainability, 4.

Bantz, S. G., \& Deaton, M. L. (2006). Understanding U.S. Biodiesel Industry Growth using System Dynamics Modeling. Proceedings of the 2006 System and Information Engineering Design Symposium. http://dx.doi.org/10.1109/SIEDS.2006.278731

Birur, D. K., Hertel, T. W., \& Tyner, W. E. (2007). The Biofuels Boom: Implications for World Food Markets. Paper presented for Food Economy Conference Sponsored by the Dutch Ministry of Agriculture. The Hague.

Fapri, F. A. (2007). Impact of a 15 Billion Gallon Biofuel Use Mandate. Staff Report.

Forrester, J. W. (1961). Industrial Dynamics. Cambridge, Massachusetts: Productivity Press-MIT.

Franco, C. J., Ochoa, M. C., \& Florez, A. M. (2009). System Dynamics Approach to Biofuels in Colombia.

Hanim, A. (2014, April 26). Palm oil biodiesel programme to cover all of Malaysia by July. Retrieved from The Star.

Hidayatno, A., Sutrisno, A., Zagloel, Y. M., \& Purwanto, W. W. (2011). System Dynamics Sustainability Model of Palm-Oil Based Biodiesel Production Chain in Indonesia. International Journal of Engineering \& Technology IJET-IJENS, 11(3).

Lopez, G. P., \& Laan, T. (2008). Biofuels-At What Cost? Government support for biodiesel in Malaysia. Geneva, Switzerland: Global Subsidies Initiative (GSI) of the International Institute for Sustainable Development (IISD).

Meadows, D. (1970). Dynamics of Commodity Production Cycles. Cambridge: Wright-Allen.

MPOB. (2014). Malaysia Oil Palm Statistics 2014. Malaysia Palm Oil Board.

Papachristos, G., \& Adamides, E. (2012). System Dynamics Modeling for Assessing Promotion Strategiess of Biofuels Used in Land Transportation. The 30th International Conference of the System Dynamics Society. St. Gallen, Switzerland.

Ramli, A., Abas, R., \& Ayatollah. (2007). Impact of Palm Oil-based Biodiesel Demand on Palm Oil Price. Oil Palm Industry Economic Journal, 7(2), 19-27.

Shri Dewi, A., Ali, A. M., \& Alias, M. H. (2014). Impact of Biodiesel Blend Mandate (B10) on the Malaysian Palm Oil Industry. Jurnal Ekonomi Malaysia, 48(2), 29-40. http://dx.doi.org/10.17576/jem -2014-4802-03

Shri Dewi, A., Arshad, F. M., Shamsudin, M. N., \& Hameed, A. A. (2011a). An Econometric Analysis of the Link between Biodiesel Demand and Malaysian Palm Oil Market. International Journal of Business and Management, 6(2).

Shri Dewi, A., Arshad, F. M., Shamsudin, M. N., \& Yusop, Z. (2011b). The Relationship between Petroleum Prices, Biodiesel Demand and Malaysia Palm Oil Prices: Evidence from Simultaneous Equations Approach. 
Banwa Journal.

Shri Dewi, A., Arshad, F. M., Yusop, Z., Shamsudin, M. N., \& Alias, M. H. (2011c). Impact of Biodiesel Demand on the Malaysian Palm Oil Industry: A Simultaneous Equations Approach. IJMS, 18(Special Issue), 73-90.

Sterman, J. D. (2000). Business Dynamics: System Thinking and Modeling for a Complex World. Boston, MA: Irwin McGraw-Hill.

Yahaya, J., Sabri, A., \& W. Kennedy, S. (2006). Impacts of Biodiesel Development on the Palm Oil Industry. Malaysian Journal of Economic Studies, XXXXIII(1\&2).

\section{Copyrights}

Copyright for this article is retained by the author(s), with first publication rights granted to the journal.

This is an open-access article distributed under the terms and conditions of the Creative Commons Attribution license (http://creativecommons.org/licenses/by/3.0/). 